\title{
The Toxicity, Persistence and Mode of Actions of Selected Botanical Pesticides in Africa against Insect Pests in Common Beans, $P$, vulgaris: A Review
}

\author{
Nelson Mpumi, Kelvin Mtei, Revocatus Machunda, Patrick A. Ndakidemi \\ School of Materials, Energy, Water and Environmental Sciences, Nelson Mandela African Institution of Science \\ and Technology, Arusha, Tanzania \\ Email: mpumin@nm-aist.ac.tz
}

Received 18 December 2015; accepted 23 January 2016; published 26 January 2016

Copyright (C) 2016 by authors and Scientific Research Publishing Inc. This work is licensed under the Creative Commons Attribution International License (CC BY). http://creativecommons.org/licenses/by/4.0/

\section{(c) (i) Open Access}

\begin{abstract}
Common beans are affected by many insect pests such as bean leaf beetle, aphids, legume pod borer and bean beetles. Traditional and cultural practices such as site selection, crop rotation, intercropping and seed selection, sowing date are used to reduce the infestation of insect pests of common beans in the field and in storage rooms. Natural enemies such as predators, parasitoids and pathogens can control the insect pests. Synthetic pesticides such as cypermethion, carbaryl, and lambda-cyhalothrin have reported to be effective, but are toxic to people, destroy natural enemies and contaminate the environment. Botanical pesticides are the promising alternatives. This review paper explains toxicity, persistence and mode of actions of active ingredients of botanical pesticides. Rotenone from $T$. vogelii has the oral lethal dose $\left(L D_{50}\right)$ of $132-1500 \mathrm{mg} / \mathrm{kg}$ to mammals. It delays the electron transport chain in mitochondria of the insects and limits the cellular energy production. Azadirachtin is antifeedant and growth disruptor of insects. It has low toxicity to mammals. The oral $\mathrm{LD}_{50}$ in mammals is greater than $3540 \mathrm{mg} / \mathrm{kg}$. Azadirachtin displays strong effects on chemoreceptors of the insects. Pyrethrins are axonic poisons and have repellent effects to insects. It is less toxic to mammals with the $L D_{50}$ of about $1500 \mathrm{mg} / \mathrm{Kg}$. It attacks the nervous systems of insects. Sesquiterpene lactones from T. diversifolia, Pentacyclic triterpenoids from Lantana camara, Vernodalin, Vernodalol and Epivernodalol from V. amygdalina have repellent and feeding deterrents chemicals which discourage the insects from feeding the crop. Most active ingredients of botanical pesticides have short life span in the environment.
\end{abstract}

\section{Keywords}

Toxicity, Persistence, Botanical Pesticides, Mode of Actions, Half Life 


\section{Introduction}

Currently, synthetic pesticides are used in controlling crops insect pests and have usually provided strong defense against insect pests [1]. Synthetic pesticides have paid off and contributed to increase in crop yields of up to four times the value of the applied pesticides [2]. Synthetic pesticides work quickly, and are not labour intensive [3]. Besides of being used widely, they are strong in controlling insect pests. However, their availability is unreliable in distant rural areas, because they are diluted to ineffective concentrations by dishonest traders, they are toxic to people and contaminate the environment [4]. Also, synthetic pesticides and their metabolites have high persistence in soil, water and crops themselves and therefore affect environment and the health of human being during preparation, application and the consumption of crops. These constraints of synthetic pesticides have led to increased interest in the application of botanical pesticides for crop protection in the field and during storage [5].

Botanical pesticides are naturally occurring chemicals extracted from plants [6] [7]. They are also called natural insecticides [6]. Botanical pesticides are cheaply available and easy to prepare and use [8], environmentally friend, difficult to contaminate farmers during preparation and use and therefore, safer than synthetic pesticides. Also they are friend to the health of human beings because they are less persistent in the environment, less toxicity and less harmful to beneficial insects [8] [9]. The active ingredients of botanical pesticides degrade rapidly in sunlight, air, and moisture and are readily broken down by detoxification enzymes [6] [7]. Commercially, botanical pesticides are cheap and in this case are viable to small-holder farmers and the growing economy of Africa.

In agricultural practices, the insect pests affecting the bean production include: bean stem maggot, Ophiomyia spp, bean foliage beetles, Ootheca spp, aphids, Aphis fabae, flower beetles, Mylabris variabilis, leaf eating caterpillars and legume pod borers [10]. The insect pests affecting the bean production in northern part of Tanzania include; bean stem maggot, Ootheca, beetle, flower beetle, leaf eating caterpillar, pod borer and aphids [11]. Insect pests reduce crop production yield because they consume plant tissues such as pod suckers, accelerating leaf senescence and contaminate the entire crops in the field which lead to poor food quality [12] [13].

It is estimated that, about $30 \%-40 \%$ of crop loss in preharvest and postharvest worldwide is due to pests [14]. Therefore, insect pests limit much of the productivity gain made through agricultural innovations. Most smallholder farmers in sub-Saharan Africa in which the use of modern technology is poor, overcome the problem of crop loss through insect pests by the use of traditional methods [15] [16]. This includes mixing more than one crop in the farm field at the same time [17] which is known as intercropping. In northern part of Tanzania, small-holder farmers practice both intercropping and monocroping system [18]. Common beans, for example, are either intercropped with maize or grown alone for nutritional values such as protein, iron and zinc supplements and for good health including brain development [19] [20]. However, these traditional methods employed by small holder farmers to control insect pests of common beans are less effective. Therefore, the use of botanical pesticides is a promising means for controlling insect pests in common beans. But also there is limited scientific information of the toxicity, persistence and mode of action of botanical pesticides active ingredients for proper use to control insect pests in common beans.

This review paper concentrates on common practices used to control insect pests of common beans, the toxicity, persistence, and mode of action of some of active ingredients of botanical pesticides including Tephrosia vogelii, Vernonia amygdalina, Tithonia diversifolia and Lantana camara, Neem, Azadirachta indica and pyrethrum, Chrysanthemum cinerariifolium as the alternatives of controlling common bean insect pests in the farmers' field, and in storage rooms and increase the possibility of safe food and environmental friendly farming and storage practices [5].

\section{Common Practices Used to Control Insect Pests of Common Beans in the Field}

Field insect pests infestation is a very serious problem because life stages of insects cause economic damage and deteriorates the crops to be harvested and food products to be stored [21]. Field insect pests infestation cause products lose in the field and some insect life stages are carried up to the storage rooms in which the damage can be estimated up to $9 \%$ in developed countries and up to $20 \%$ or more in developing countries [22]. There are practices used to control the insect pests of the crop in the field. Those practices used by small-holder farmers include traditional, biological, synthetic and botanical pesticides application. 


\subsection{Traditional Practices}

There are many traditional practices, whereby smallholder farmers use to reduce infestations of the insect pests in the farms. Those traditional practices are also called cultural practices. Cultural practices such as site selection, crop rotation, and cultivar and seed selection, proper sowing date can reduce the infestation of certain insect pests [23]. For instance, aphid infestation in wheat and common beans is reduced by early sowing time [24] and also, affect the population of bean stem maggot, Ophiomyia sp, bean foliage beetle, Ootheca, aphids and other arthropods attacking common beans in the field [25]. Apart from that, [26] reported that; planting in either late time or off-season lead to higher infestation of bean stem maggot in the farms grown common beans. In other agronomic studies, row spacing and plant density, weed control and stubble retention have been used to control bean stem maggot [27]. Other studies have reported that, sloping sites and border hedgerows which reduce wind speed promote aphid landing and affects aphids and Ootheca species distribution [28]. Increasing plant density from 22 bean plant $/ \mathrm{m}^{2}$ to 33 bean plant $/ \mathrm{m}^{2}$ was found to decrease common bean virus incidence transmitted by aphids by $10 \%$ - 20\% [29]. Also [29] reported that; planting cereal border around faba bean field reduces the spread of non-persistently bean transmitted virus. However, cultural practices are not very effective although they are safe and cheap. Therefore, there is a need of conducting detailed study on the use of botanical pesticides for controlling insect pests in the farms of small-holder farmers.

\subsection{Biological Control Methods}

Biological control is defined as the reduction of pest populations (insects, mites, weeds and plant diseases) using other living organisms [30]. Insect pests are suppressed by naturally occurring organisms and environmental factors which are called natural enemies or natural control. Natural enemies of insect pests are known as biological control agents. Natural enemies are organisms which kill, decrease the reproductive potential, or reduce the number of another organism [30]. Those natural enemies include predators, parasitoids, and pathogens.

A predator is an organism that attacks, kills, and feeds on several or many other organisms in life time. Some predators are specialized, which means feeding on only one or few preys while most are generalized meaning that, feeding on variety of organisms [30]. Predators include spiders, lacewings, lady beetles, ground beetles, rove beetles, hover flies, and true bugs [30]. These organisms kill and feed in the insect pests affecting common beans. Ladybird beetles, family Coccinelidea, both adults and larvae feeds on aphids [31] and therefore reduce the population of aphids. Ladybird beetles are stronger, larger and usually more intelligent than the prey and therefore attack several hosts in a short period of time [32].

Parasitoids are insects which parasitize and kill other invertebrates. Many species of wasps and some flies are parasitoids. Some of species of parasitoids, when are in immature stage develops on or within a single insect host forming mummies and therefore killing the host [31]. Parasitoids are parasitic when are in immature stage and kill their hosts as they reach maturity [30]. Species of entomopathogenic fungi infest aphids through the cuticle and finally killing the host [32]. Apart from that, species in the Braconidae family develop as endopara- sitoids of aphids whereby the larva complete their development in the host [23]. Aphids are also controlled by spinosad. It is a biologically derived insecticide produced by the actinomycete, Saccharopolyspora spinosa, a bacterial organ isolated from soil [34].

Pathogens are important in biological control of many pests including insect pests, nematodes, mites and weeds [31]. Pathogen such as Bacillus thuringiensis, controls certain caterpillars, beetles and flies but does not affect other arthropods. Biological control is safe and eco-friendly. Therefore, detail studies are needed on toxicity, persistence and mode of actions of active ingredients of botanical pesticides for safety use by small holder farmers and support the present of natural enemies.

\subsection{Chemical Pesticides}

Worldwide, it is estimated that approximately 1.8 billion people engage in agriculture and most of them use approximately 5.6 billion pounds of synthetic pesticides to protect the food and commercial products that they produce [35]. Pesticide use in Africa accounts for only 2\% - 4\% of the global pesticide market [36]. Synthetic pesticides are reported to be effective, reliable against a wide range of insect pests, quick acting and easily tested for new insect pests [37]. Pesticides chemicals such as endosulfan, diazinon and lindane have been identified by several National bean programs and Research organizations to provide protection to germinating bean plants at a 
time when they are most vulnerable to attacks especially bean stem maggot [38]. Cypermethion, carbaryl, and Lambda-cyhalothrin have shown efficacy to control the pests in the field and in the storage rooms [39]. However, many of the synthetic pesticides such as endosulfan and lindane are either banned, or are expensive to smallholder farmers in Africa, and are persistence in the environment [40].

Also, according to the Stockholm Convention, among the 12 Persistence Organic Pollutants (POPs), nine are pesticides including aldrin, chlordane, dichlorodiphenyltrichloroethane (DDT), dieldrin, endrin, heptachlor, hexachlorobenzene (HCB), mirex and toxaphene [40]. Those POPs are associated with human health problems such as cancer. The study done by [40] reported that mothers who are exposed to lindane, can accumulate it into breast milk, o, p-dichlorodiphenyldichloroethane (DDD) can accumulate in maternal serum and total dichlorodiphenyltrichloroethane (DDT) can accumulate in the umbilical serum [40]. This reflects their potential placental and breast milk transfer to her child during pregnancy and lactation [40]. In response to the high costs and the negative side effects of synthetic pesticides to the health of human being [41], there is a need for studying botanical pesticides in detail which are affordable and have less or no health problems to the applicators, consumers and do not contaminate the environment to replace the synthetic pesticides.

\subsection{Botanical Pesticides}

Botanical pesticides have long been publicized as attractive alternatives to synthetic insecticides for pest management since they pose either little or no threat to the environment, to ecosystems and to human health [42]. In the middle of the 17th century, pyrethrin, nicotine and rotenone form pyrethrum, tobacco and Tephrosia spp respectively were recognized as effective insect control agents [6]. Hence, mankind has used plant extracts for thousands of years to the prevent diseases, treatment of disease, as insecticides to control microbial growth, weeds and many more functions [43]. Therefore, many plants which were used for medicinal purposes locally, also demonstrated potential as insect control agents [44]. Botanical products like tobacco extracts, neem oil and extracts, have found promising and useful for bean pests control [45]. Similarly, Tephrosia vogelii, Azadirachta indica, Annona squamosa, chilli paper, Cupscum frutensces, Allium sativa are reported to control insect pests of beans and cowpeas successfully [46]. Aristolochia ringens and Alium sativum have antifeedants, food poisons, contact poisons and repellents against Sitophilus zeamais [44]. Pesticidal plants such as Tobacco, Nicotiana tabacum, Neem, Azadirachta indica, Garlic, Allium sativum, Eucalyptus, Eucalyptus camaldulemsis and Mehogony, Swietenia mehogany, have been reported in controlling aphids attacking bean plants [47]. Normally, botanical pesticides comprise a mixture of bioactive compounds with many have advantages in terms of efficacy and short life span [48]. Table 1 shows the toxicity of some active ingredients of botanical pesticides

The botanical pesticides are generally pest-specific and are relatively harmless to non-target organisms including man and natural enemies of insect pests [6] [49], and environmentally ecofriend, degrade rapidly in sunlight, air, and moisture, so they are less persistence in the environment, and are rapid in action to the insect pests, no adverse effect on plant growth, seed viability and cooking quality of the grains and are less expensive and easily available in the farmers natural environment [41]. Now it becomes necessary to search for the alternative

Table 1. Toxicity of certain botanical pesticides active ingredients (mg/kg).

\begin{tabular}{cccc}
\hline Generic Name & Oral $\mathbf{L D}_{\mathbf{5 0}}$ & Dermal $\mathbf{L D}_{\mathbf{5 0}}$ & Signal Word \\
\hline Pyrethrins & $1200-1500$ & $>1800$ & Caution \\
Rotenone & $60-1500^{*}$ & $940-3000$ & Caution \\
Sabadilla & 4,000 & - & Caution \\
Ryania & $750-1200$ & 4000 & Caution \\
Nicotine & $50-60$ & 50 & Danger \\
d-Limonene & $>5000$ & - & Caution \\
Linalool & $2440-3180$ & $3578-8374$ & Caution \\
Neem & 13,000 & - & Caution
\end{tabular}

\footnotetext{
*Toxicity varies greatly depending on type of solvent used as carrier; Source: [6].
} 
means of insect pests control, which can minimize the use of synthetic pesticides. This work reviews the toxicity, persistence and mode of actions of some of botanical pesticides which are locally available plant materials in our environment.

\section{Toxicity and Persistence of Some of Active Ingredients from Botanical Pesticides}

Although botanical pesticides can be used as alternatives to synthetic pesticides but the toxicity of the chemical compounds extracted from botanical pesticides to insect pests and humans, persistence to the environment and mode of actions to insect pests are not clear [7]. Therefore, this part, intends to explain the toxicity and persistence of pyrethrin from pyrethrum, rotenone from $T$. vogelii, azadirachtin from Azadirachta indica, and some active chemical compounds from V. amygdalina, L. camara, and T. diversifolia. These botanical pesticides are selected, because are commonly found around our homes, along the roads, river banks and bush lands in northern part of Tanzania [11] and may be used as botanical pesticides.

\subsection{Rotenone}

Rotenone, Figure 1 is contained in large amount in plant species especially Tephrosia, Derris, and Lonchocarpus [50]. All these plants are in the family fabaceae in Leguminosae. Rotenone (Figure 1) is used as natural insecticide, piscicide, and pesticide [7]. It is a relatively low toxicity insecticide for use in gardens but is highly toxic to fish and is sometimes used to eliminate unwanted fish from lakes [50]. It occurs naturally in the seeds, stems, leaves and the roots of plants in fabaceae family. It was the first described member of the family of chemical compounds known as rotenoids [51].

The $\mathrm{LD}_{50}$ of rotenone (Figure 1) for rats is $132-1500 \mathrm{mg} / \mathrm{kg}$ [6] [7]. In human being, rotenone is moderately toxic with an oral $\mathrm{LD}_{50}$ ranges from 300 to $1500 \mathrm{mg} / \mathrm{kg}$ [7] [51]. This compound (Figure 1) is highly toxic to fish and insects because it is lipophilic in nature [50]. The respiratory mechanism of fish is directly linked to water through the gills and in insect is directly exposed through trachea whereby rotenone is easily taken up through the gills or trachea into the bloodstream of fish, and insects respectively resulting to death [50].

However, rotenone is less toxic to mammals and birds since the route of ingestion is through the digestive tract whereby the compound is easily broken down to less toxic compounds before toxic quantities can enter the bloodstream [6] [7] [50] [51]. Rotenone is rapidly broken down by sunlight which is both an advantage and disadvantage [50]. Since it breaks down rapidly, it does not accumulate in the environment and less harmful to non-target organisms [6]. However, it must be re-applied at short intervals and is usually applied in the early morning or in the evening to avoid degradation of it by sunlight [7]. In water, the rate of decomposition depends upon several factors, including temperature, $\mathrm{pH}$, turbidity of water and sunlight. The half life of rotenone is four days [6] [7] [50] [51]. The half-life of rotenone in natural waters ranges from half a day at $24^{\circ} \mathrm{C}$ to 3.5 days at $0^{\circ} \mathrm{C}$ [6]. However, there are limited scientific information about toxicity of rotenone to organisms and persistence of it in the environment. Therefore, detail studies are needed on the toxicity of rotenone to various animals and persistence of it in the environment for use it sustainably as botanical pesticide.<smiles>C=C(C)[C@H]1Cc2c(ccc3c2O[C@H]2COc4cc(OC)c(OC)cc4[C@@H]2C3=O)O1</smiles>

Figure 1. Chemical structure of rotenone. 


\subsection{Azadirachtin from Neem, Azadirachta indica}

Neem tree is in Meliaceae family possessing bitter triterpenoids [52]. The active compound in the neem is azadirachtin which is found in the leaves, and also concentrated in the seeds [53]. It is a bitter, complex chemical compound which belongs to the limonoid group and it show strong biological activities among various insect pests [53]. This compound (Figure 2) is a feeding deterrent and growth regulator [51].

This compound (Figure 2) can affect about 200 species of insects by acting as antifeedant and growth disruptor. Azadirachtin has a toxicity and fascinating effect on insects ( $\mathrm{LD}_{50}$ (S. littoralis), $15 \mu \mathrm{g} / \mathrm{g}$ ) [53]. It has very low toxicity to mammals whereby the $\mathrm{LD}_{50}$ in rats is greater than $3540 \mathrm{mg} / \mathrm{kg}$ which make it practically non-toxic to mammals [53] and also has been reported to be non mutagenic [52]. Azadirachtin has been found to degrade rapidly under environmental factors such as UV radiation in sunlight, heat, air moisture, acidity and enzymes present in foliar surfaces [53]. The half-life of azadirachtin has been found to be between 48 minutes and 3.98 days under Ultraviolet (UV) light and sunlight and 2.47 days on leaf surface [6] [51]. Therefore, there is a need to use azadirachtin as environmentally compatible insecticides, with selective toxicity to targeted pests, low toxic to plants and mammals and environmental friendly desired stability.

\subsection{Pyrethrin from Pyrethrum, Tanacetum cinerariifolium (Chrysanthemum cinerariifolium)}

Pyrethrum is powdered, dried flower head of the pyrethrum daisy, Tanacetum cinerariaefolium and pyrethrins active compound from pyrethrum with six related insecticidal compounds which occur naturally [6]. There is pyrethrin I and pyrethrin II. The compounds related to pyrethrin I contain methyl group $\left(-\mathrm{CH}_{3}\right)$ and the compound related to pyrethrin II contain $-\mathrm{CO}_{2} \mathrm{CH}_{3}$ group [51] [52]. The general chemical formula of pyrethrin and the six related pyrethrin compounds are shown in Figure 3 and Figure 4.

Pyrethrins are axonic poisons and have an insect repellent effect when present in little amount [6]. They are harmful to fish, but are less toxic to mammals and birds than many synthetic insecticides. In pure form, the rat oral $L D_{50}$ is $1200-1500 \mathrm{mg} / \mathrm{kg}$ [51]. The technical grade of pyrethrum is less toxic to rat with the $\mathrm{LD}_{50}$ of about $1500 \mathrm{mg} / \mathrm{Kg}$. Pyrethrins degrade easily when is exposed to the environment moisture, air and the sunlight [51]. The half-life of pyrethrins in the environment and field-grown bell pepper fruit is 2 hours or less [6]. However, there are limited scientific information about toxicity of pyrethrins compounds to various organisms and persistence of it in the environment. Therefore, detail studies are needed about the toxicity of pyrethrins compounds to various organisms and persistence of it in the environment for use it sustainably as botanical pesticide.

\subsection{Sesquiterpene Lactones from T, diversifolia}

Many classes of secondary metabolites which are isolated from the Tithonia diversifolia extracts include diterpenoids, flavonoids, sesquiterpene lactones (Figure 5) and chlorogenic acids derivatives [54] [55]. However,

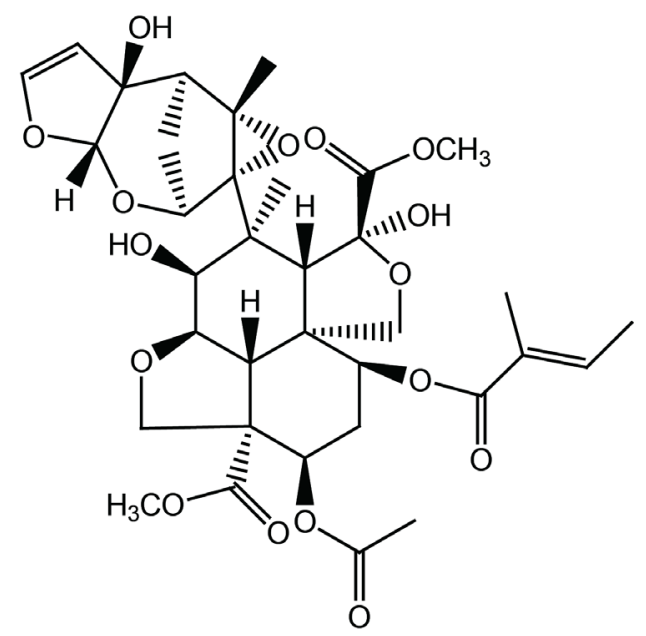

Figure 2. Chemical structure of azadirachtin. 


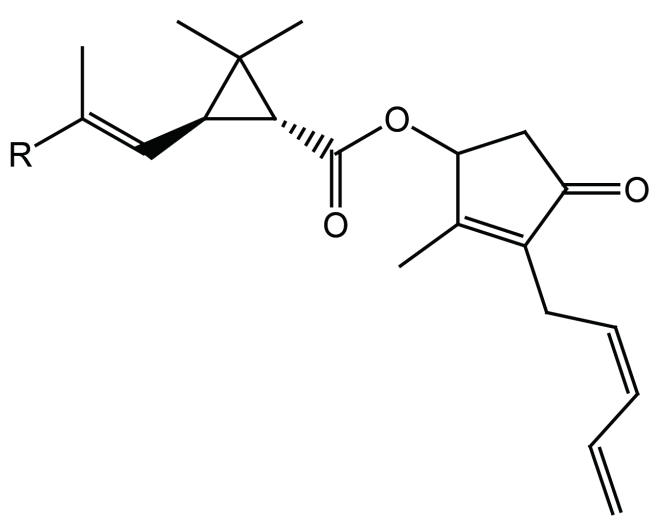

Figure 3. General chemical formula of pyrethrum, Pyrethrum I, R $=\mathrm{CH}_{3}$, Pyrethrum II, $\mathrm{R}=\mathrm{CO}_{2} \mathrm{CH}_{3}$.

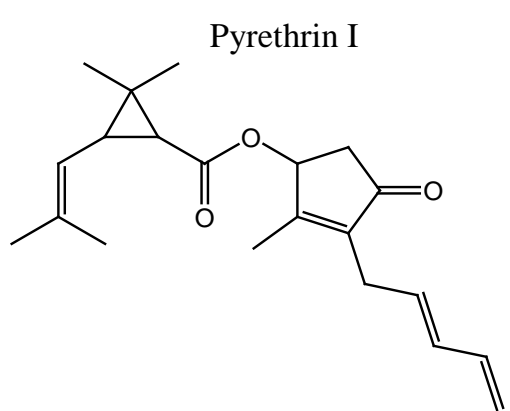

$\mathrm{C}_{21} \mathrm{H}_{28} \mathrm{O}_{3}$
Pyrethrin II<smiles>C=CC=CCC1=C(C)C(OC(=O)C2C(C=C(C)C(=O)OC)C2(C)C)CC1=O</smiles>

$\mathrm{C}_{22} \mathrm{H}_{28} \mathrm{O}_{5}$
Cinerin I<smiles>C/C=C/CC1=C(C)C(OC(=O)C2C(C=C(C)C)C2(C)C)CC1=O</smiles>

$\mathrm{C}_{20} \mathrm{H}_{28} \mathrm{O}_{3}$
Jasmolin I<smiles>CCC=CCC1=C(C)C(OC(=O)C2C(C=C(C)C)C2(C)C)CC1=O</smiles>

$\mathrm{C}_{21} \mathrm{H}_{30} \mathrm{O}_{3}$

Figure 4. Chemical structures of the six related pyrethrin compounds.

Cinerin II<smiles>C/C=C/CC1=C(C)C(OC(=O)C2C(/C=C(\C)C(=O)OC)C2(C)C)CC1=O</smiles>

$\mathrm{C}_{21} \mathrm{H}_{28} \mathrm{O}_{5}$<smiles>CC/C=C/CC1=C(C)C(OC(=O)C2C(/C=C(\C)C(=O)OC)C2(C)[AlH2])CC1=O</smiles>

$\mathrm{C}_{22} \mathrm{H}_{30} \mathrm{O}_{5}$

the most abundant terpernoids in Tithonia diversifolia are sesquiterpene lactones [55]. But tagitinins compounds (Figure 5) which are in sesquiterpene lactones class are the most studied [56]. The sesquiterpene lactones and diterpenoids have biological activities [16] and contribute to inflammatory activity [55]. T. diversifosia is used as traditional medicine in constipation, stomach pains, indigestion, sore throat, liver pains and to treat malaria [57]. [56] reported that; the extracts of $T$. diversifolia of $10 \mathrm{mg} / \mathrm{kg}$ and $100 \mathrm{mg} / \mathrm{kg}$ administered to rats for 90 days were relatively safe with some toxicity observed at $100 \mathrm{mg} / \mathrm{kg}$. However, the later can cause damage of the liver, the kidneys and, to a lesser extent, the heart [56]. The liver damage observed at higher doses of aqueous extracts of Tithonia diversifolia may result from the Chlorogenic acid, while kidney damage results from the Sesquiterpene lactones [55] [56]. However, no clear information about toxicity of these compounds from Tithonia diversifolia.

\subsection{Pentacyclic Triterpenoids from Lantana camara}

Lantana camara is recognized to be toxic to cattle, sheep, horses, dogs and goats [58]. The active ingredients causing toxicity of Lantana camara in grazing animals is pentacyclic triterpenoids [47] (Figure 6). It is one of 


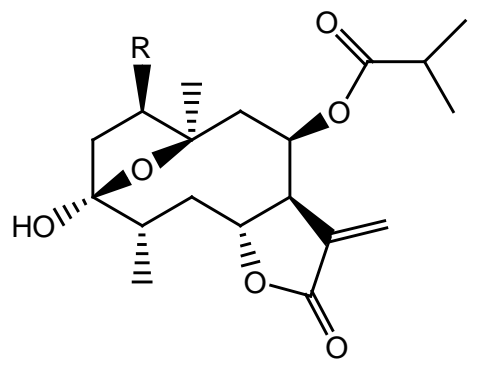

$1 \mathrm{R}=\mathrm{OH}$

1a $\mathrm{R}=\mathrm{OAc}$

Tagitinins A

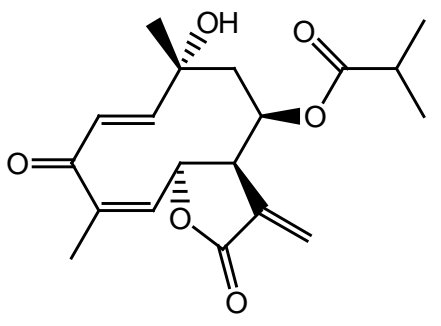

Tagitinins C

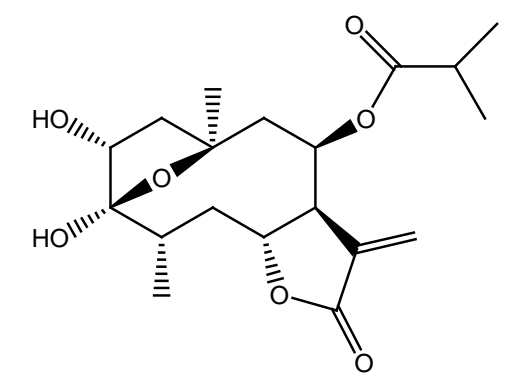

2 alpha -hydroxytirotundin, tagitinins $\mathrm{A}$ isomer

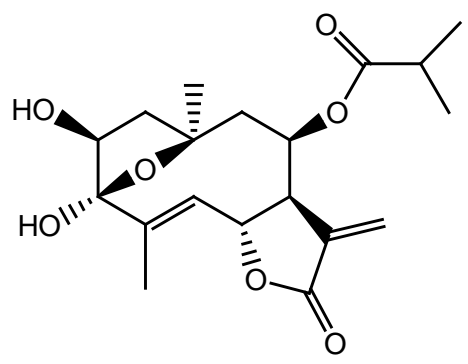

Tagitinins B

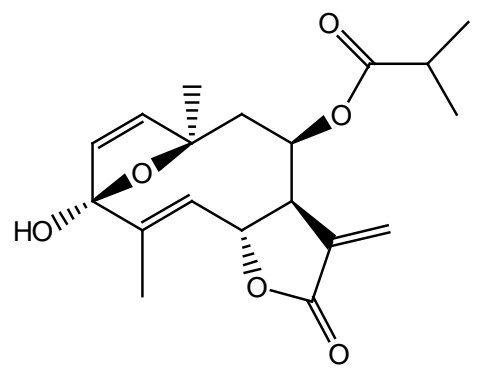

Tagitinins F

Figure 5. Chemical structures of some sesquiterpene lactones from leaves of $T$. diversifolia. Source: [57].

terpernoids, which result in liver damage and photosensitivity [59]. The toxicity of $L$. camara to human being is undetermined, whereby numerous studies suggest that; ingestion of berries from Lantana camara can be toxic to humans [47]. [60] reported that; leaf extract of $L$. camara had excellent repellent, moderate toxic and antifeedant activities. However, other studies have found evidence which suggests that ingestion of $L$. camara fruit, poses no risk to humans and is in fact edible when ripe [47]. Studies conducted in India have found that; Lantana camara leaves can display antimicrobial, fungicidal and insecticidal properties [61]. L. camara has also been used in traditional herbal medicines for treating a variety of ailments, such as cancer, skin itches, leprosy, rabies, chicken pox, measles, asthma and ulcers [61]. Lantana camara has been tested as an alternative to fumigants in stored grains [62]. Therefore, there is a need of finding out more information about the toxicity of Lantana camara to the health of human being.

\subsection{Vernodalin, Vernodalol and Epivernodalol from V. amygdalina}

Vernodalin, Vernodalol and Epivernodalol (Figure 7) are sesquiterpene lactone compounds from the members of Asteraceae family. They are the major bioactive constituents isolated from Vernonia species [63]. Phytochemical 


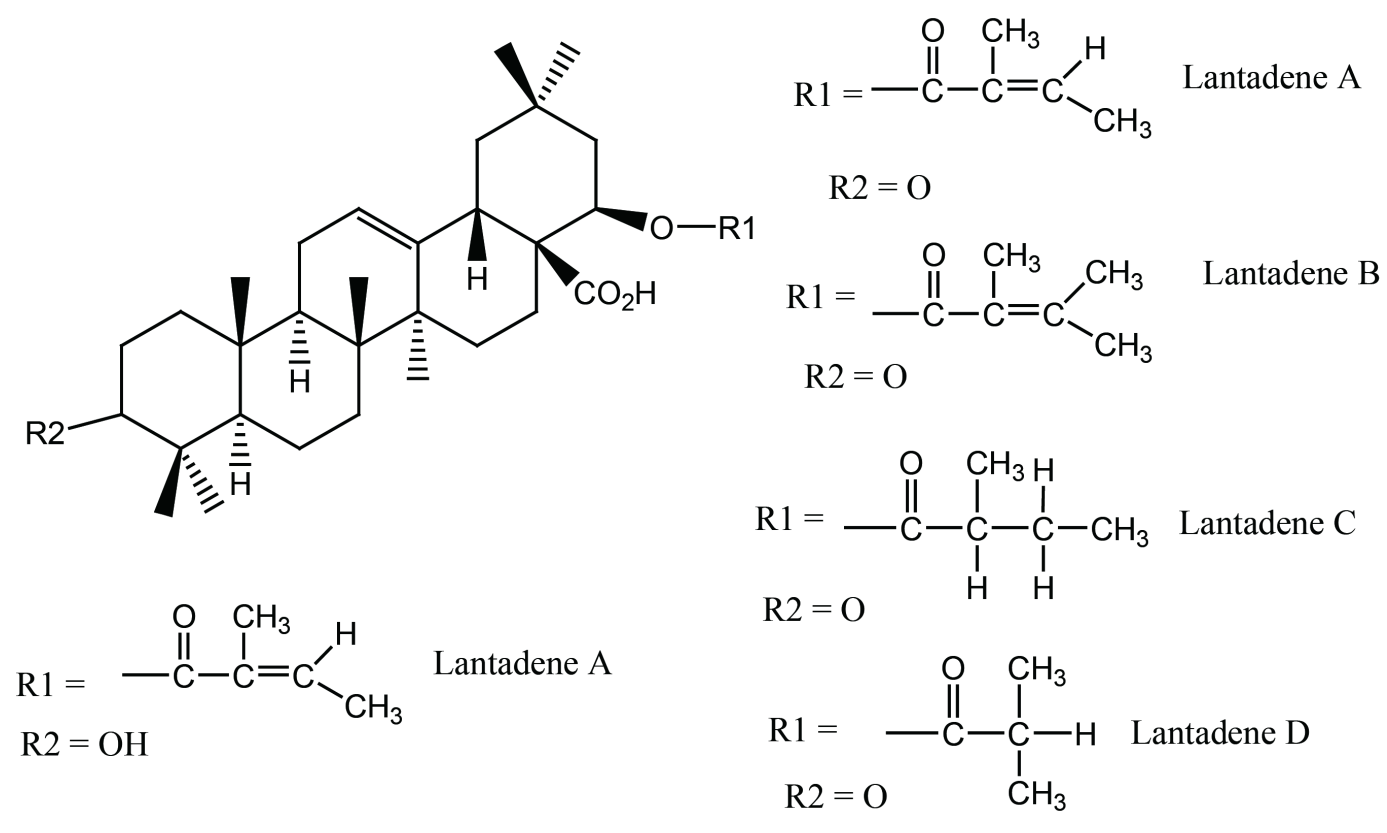

Figure 6. Chemical structures of Lantadenes (Pentacyclic triterpenoids). Source: [47].<smiles>C=CC12COC(=O)C(=C)C1(C)C1OC(=O)C(=C)C1C(OC(=O)C(=C)CO)C2</smiles>

Vamodalin<smiles>C=CC12COC(=O)C(=C)C1(C)C(O)C(C(=C)C(C)=O)C(OC(=O)C(=C)CO)C2</smiles>

Vemodalol<smiles>C=C[C@]12COC(=O)C(=C)[C@@]1(C)[C@H](C)[C@@H](C(=C)C(=O)OC)[C@@H](OC(=O)C(=C)CO)C2</smiles>

Epivemodalol

Figure 7. Chemical structures of isolated compounds from V. amygdalina. Source: [64] [65].

analysis of leaves of Vernonia amygdalina revealed the presence of important natural products vernolide and vernodalol [64] [65]. The toxicity of these compounds is very low to human being [42]. The $\mathrm{LD}_{50}$ was tested in mice and extrapolated to be $1265 \mathrm{mg} / \mathrm{kg}$ [63]. The possibility of using nontoxic deterrents and repellents as crop protectants is intuitively attractive [42] since have little effects to health of human being. These sesquiterpene lactones were found to be active on gram positive bacteria and vernolides has reported to show high antifungal activities [66]. Study on the efficacy of $V$. amygdalina on field insect pests in cowpea (M. sjostedti and B. tabaci) showed effectiveness when it was applied in two weeks interval after crop emergency [67]. These chemicals have deterrent and repellent properties toward insect pests.

Repellent and feeding deterrent chemicals from pesticidal plants discourage the insects from feeding it. Many compounds or extracts from medicinal plants which demonstrated antifeedant effects lack toxicity if ingested [42] [68]. Sesquiterpene lactone disappears in the environment in 90 days and the disappearance is faster when 
compared with synthetic pesticides [63]. However, there is little information about the toxicity, persistence and mode of action of $V$. amygdalina suitable for the protection of the environment from the botanical pesticides metabolites contamination.

\section{Mode of Action of Active Compounds from Botanical Pesticides}

Despite the suggestion, of using botanical pesticides as alternatives to synthetic pesticides but there are limited information about the mode of actions of the chemical compounds to insect pests. Therefore, this part intends to explain the mode of actions of pyrethrin from pyrethrum, rotenone from T. vogelii, azadirachtin from Azadirachta indica, and some active chemical compounds from V. amygdalina, L. camara, and T. diversifolia.

\subsection{Mode of Action of Rotenone}

Rotenone delay the electron transport chain in mitochondria of the insect pests and it is a contact and stomach poison [6] [7] [50] [51] [69]. It inhibits the transfer of electrons from iron-sulfur centers in complex I to ubiquinone and interferes with Nicotinamide adenine dinucleotide hydride (NADH) during the creation of usable cellular energy Adenosine triphosphate (ATP) [69]. In that case, Complex I is unable to pass through its electron to Complex Q, creating a back-up of electrons within the mitochondrial matrix. During this limiting process, cellular oxygen is reduced to the radical which is a reactive species. This reactive species can damage Deoxyribonucleic acid (DNA) and other components of the mitochondria [50].

\subsection{Mode of Action of Azadirachtin}

Azadirachtin displays strong antifeedant effects on chemoreceptors of the insects and discourage the insect pests to consume the plant [53]. If the insect pest continues in consuming crops sprayed with neem tree extracts, the azadirachtin blocks peptide hormone release, which results in severe growth defects and molting abnormalities [52] [70]. Finally, azadirachtin has a damaging effect on the tissues including the muscles, fat and gut of most of the insect [52].

\subsection{Mode of Action of Pyrethrins}

Pyrethrins attack the nervous systems of all insects and act like pyrethroids and DDT [6]. Axonic poison substances affect the electrical transmission of the impulses along the axon [51]. During their mode of action pyrethrins upset the sodium and potassium ion exchange process in insect nerve fibers and interfere the normal transmission of nerve impulses [6]. Pyrethrins delay the closure of voltage-gated sodium ion channels in the nerve cells of insects, resulting in repeated and extended nerve firings [51]. This hyperexcitation causes the death of the insect due to loss of motor coordination and paralysis. Sometimes insect pests may develop resistance to pyrethrum [6]. Piperonyl butoxide is paired with pyrethrin to prevent resistance by insect pests. It is synergist compound. Together, these two compounds prevent detoxification in the insect, ensuring insect death. Synergists make pyrethrin more effective, allowing lower doses to be effective [6]. Pyrethrins are effective pesticides because they selectively target insects rather than mammals due to higher insect nerve sensitivity, smaller insect body size, lower mammalian skin absorption, and more efficient mammalian hepatic metabolism [6].

\subsection{Mode of Action of Active Ingredients from T, diversifolia to Insect Pests}

The phytochemical analysis of T. diversifolia, revealed the presence of non-volatile fractions which are rich in flavonoids and sesquiterpene lactones whereas the essential oil contains mainly monoterpene hydrocarbons, such as b-ocimene, a-pinene and limonene [23]. The plant has been found to have insect feeding deterrent characteristics to insect pests [23] which have effect on chemoreceptors to discourage the insects from consuming bean plants. That is caused by the presence of 6-methoxyapigenin, sesquiterpene lactones, chologenic acids and tagitinins A, B, C and F, with diversiform, tirotundin, tithonine and sulphurein [23].

\subsection{Mode of Action of Some Active Ingredients from L. camara}

L. camara essential oil and leaves are composed of large amounts of sesquiterpene hydrocarbons, mainly $\beta$-caryophyllene [71], lantadene A, B and C which produce strong hepatotoxic response in rodents and the extracts 
have fumigant activity against Sitophilus granarius adults [72] [73]. Terpenoids, phenylpropanoids, and flavonoids are thought to be the main components which have biological activities in Lantana camara [60]. The leaves have repellent and antifeedant properties against insects [60]. Apart from that, L. camara active ingredients have acetylcholine inhibition property against insect pests [60]. It is known for its enzyme inhibition and therefore serves as an alternative to synthetic fumigants. However, there is limited information about the effectiveness, toxicity, and persistence of chemical constituents in Lantana camara.

\subsection{Mode of Action of Active Ingredients from T. diversifolia to Insect Pests}

The phytochemical analysis of $T$. diversifolia, revealed the presence of non-volatile fractions which are rich in flavonoids and sesquiterpene lactones whereas the essential oil contains mainly monoterpene hydrocarbons, such as b-ocimene, a-pinene and limonene [23]. The plant has been found to have insect feeding deterrent characteristics to insect pests [23] which have effect on chemoreceptors to discourage the insects from consuming bean plants. That is caused by the presence of 6-methoxyapigenin, sesquiterpene lactones, chlorogenic acids and tagitinins A, B, C and F, with diversiform, tirotundin, tithonine and sulphurein [23].

\section{Conclusion}

Currently, control of bean pests is achieved through the use of synthetic pesticides. But synthetic pesticides have been found to cause problems to the environment, ecology and to the health of human being. The promising alternatives, the botanical pesticides for instance the Tephrosia vogelii, Cupscum species, Vernonia species, Tagetes minuta, Ocimum gratissimum, Pyrethrum, Azadirachta indica, Lantana camara and Tithonia diversifolia can be considered to control the insect pests in the field and in the storage rooms. However, the toxicological and environmental properties of the compounds from botanical pesticides and the mode of action in insects should also be considered for the safety of our environment and the human health and insect resistance. It is known that most toxic mammalian poisons are natural products from plants although they are found to be cheap and easy available and to prepare, short life span and are ecofriendly to the environment and other animals.

\section{Acknowledgements}

This study was funded by McKnight Foundation through a grand from Bill and Melinda Gates Foundation given to The Nelson Mandela African Institution of Science and Technology (NM-AIST).

\section{References}

[1] Chikukura, L., Mvumi, B., Chikonzo, R., and Chenzara, C. (2011) Evaluation of Selected Indigenous Pesticidal Plant Powders against Stored Maize and Cowpeas Insect Pests. African Crop Science Conference Proceedings, 10, 189-192.

[2] Cooper, J. and Dobson, H. (2007) The Benefits of Pesticides to Mankind and the Environment. Crop Protection, 26, 1337-1348. http://dx.doi.org/10.1016/j.cropro.2007.03.022

[3] Weinberger, K. and Srinivasan, R. (2009) Farmers' Management of Cabbage and Cauliflower Pests in India and Their Approaches to Crop Protection. Journal of Asia-Pacific Entomology, 12, 253-259. http://dx.doi.org/10.1016/j.aspen.2009.08.003

[4] Stevenson, P.C., Kite, G.C., Lewis, G. P., Forest, F., Nyirenda, S.P., Belmain, S.R., Sileshi, G.W. and Veitch, N.C. (2012) Distinct Chemotypes of Tephrosia vogelii and Implications for Their Use in Pest Control and Soil Enrichment. Phytochemistry, 78, 135-146. http://dx.doi.org/10.1016/j.phytochem.2012.02.025

[5] Sola, P., Mvumi, B., Ogendo, J., Mponda, O., Kamanula, J., Nyirenda, S., Belmain, S. and Stevenson, P. (2014) Botanical Pesticide Production, Trade and Regulatory Mechanisms in Sub-Saharan Africa: Making a Case for Plant-Based Pesticidal Products. Food Security, 6, 369-384. http://dx.doi.org/10.1007/s12571-014-0343-7

[6] Henn, T. and Weinzierl, R. (1989) Botanical Insecticides and Insecticidal Soaps. University of Illinois at UrbanaChampaign, College of Agriculture, Cooperative Extension Service.

[7] El-Wakeil, N.E. (2013) Botanical Pesticides and Their Mode of Action. Gesunde Pflanzen, 65, 125-149. http://dx.doi.org/10.1007/s10343-013-0308-3

[8] Amoabeng, B.W., Gurr, G.M., Gitau, C.W. and Stevenson, P.C. (2014) Cost: Benefit Analysis of Botanical Insecticide Use in Cabbage: Implications for Smallholder Farmers in Developing Countries. Crop Protection, 57, 71-76.

http://dx.doi.org/10.1016/j.cropro.2013.11.019 
[9] Cortés, A.J., Monserrate, F.A., Ramírez-Villegas, J., Madriñán, S. and Blair, M.W. (2013) Drought Tolerance in Wild Plant Populations: The Case of Common Beans (Phaseolus vulgaris L.). PLoS ONE, 8, e62898. http://dx.doi.org/10.1371/journal.pone.0062898

[10] Maikai Murna, A. (2013) Development of an Integrated Pest Management Strategy for the Control of Maruca Vitrata on Cowpea in Kebbi State of Nigeria. Ph.D. Thesis, University of Greenwich, Greenwich.

[11] Mkenda, P.A., Mtei, K. and Ndakidemi, P.A. (2014) Pesticidal Efficacy of Tephrosia vogelii and Tithonia diversifolia against Field Insect Pests of Common Beans [Phaseolus vulgaris L.] within African Farming Communities. African Journal of Applied Agricultureal Sciences and Technologies, 2, 9-26.

[12] Boote, K., Jones, J., Mishoe, J. and Berger, R. (1983) Coupling Pests to Crop Growth Simulators to Predict Yield Reductions [Mathematical Models]. Phytopathology (USA), 11, 1581-1587. http://dx.doi.org/10.1094/Phyto-73-1581

[13] Ampofo, J. and Massomo, S. (1998) Some Cultural Strategies for Management of Bean Stem Maggots (Diptera: Agromyzidae) on Beans in Tanzania. African Crop Science Journal, 6, 351-356. http://dx.doi.org/10.4314/acsj.v6i4.27785

[14] Oerke, E.-C. and Dehne, H.-W. (2004) Safeguarding Production—Losses in Major Crops and the Role of Crop Protection. Crop Protection, 23, 275-285. http://dx.doi.org/10.1016/j.cropro.2003.10.001

[15] Muhammad, B.Y. and Awaisu, A. (2008) The Need for Enhancement of Research, Development, and Commercialization of Natural Medicinal Products in Nigeria: Lessons from the Malaysian Experience. African Journal of Traditional, Complementary, and Alternative Medicines, 5, 120-130.

[16] Obembe, D. (2013) Knowledge Sharing, Sustained Relationships and the Habitus. Management Learning, 44, $355-372$. http://dx.doi.org/10.1177/1350507612450988

[17] Altieri, M.A. (2004) Linking Ecologists and Traditional Farmers in the Search for Sustainable Agriculture. Frontiers in Ecology and the Environment, 2, 35-42. http://dx.doi.org/10.1890/1540-9295(2004)002[0035:LEATFI]2.0.CO;2

[18] Tsubo, M., Walker, S. and Ogindo, H. (2005) A Simulation Model of Cereal-Legume Intercropping Systems for SemiArid Regions: I. Model development. Field Crops Research, 93, 10-22. http://dx.doi.org/10.1016/j.fcr.2004.09.002

[19] Robinson, J. (2005) Pests and Integrated Pest Management in Western Equatoria, Southern Sudan. International Journal of Tropical Insect Science, 25, 224-235. http://dx.doi.org/10.1079/IJT200582

[20] Fivawo, N. and Msolla, S. (2012) The Diversity of Common Bean Landraces in Tanzania. TaJONAS: Tanzania Journal of Natural and Applied Sciences, 2, 337-351.

[21] Upadhyay, R. and Ahmad, S. (2011) Management Strategies for Control of Stored Grain Insect Pests in Farmer Stores and Public Ware Houses. World Journal of Agricultural Science, 7, 527-549.

[22] Phillips, T.W. and Throne, J.E. (2009) Biorational Approaches to Managing Stored-Product Insects. Annual Review of Entomology, 55, 375-397. http://dx.doi.org/10.1146/annurev.ento.54.110807.090451

[23] Mwanauta, R.W., Mtei, K.A. and Ndakidemi, P.A. (2014) Prospective Bioactive Compounds from Vernonia amygdalina, Lippia javanica, Dysphania ambrosioides and Tithonia diversifolia in Controlling Legume Insect Pests. Agricultural Sciences, 5, 1129-1139. http://dx.doi.org/10.4236/as.2014.512123

[24] Acreman, T. and Dixon, A. (1985) Developmental Patterns in Wheat and Resistance to Cereal Aphids. Crop Protection, 4, 322-328. http://dx.doi.org/10.1016/0261-2194(85)90034-1

[25] Way, M. and Banks, C. (1967) Intra-Specific Mechanisms in Relation to the Natural Regulation of Numbers of Aphis fabae Scop. Annals of Applied Biology, 59, 189-205. http://dx.doi.org/10.1111/j.1744-7348.1967.tb04428.x

[26] Nderitu, J., Kayumbo, H. and Mueke, J. (1990) Effect of Date of Sowing on Beanfly Infestation of the Bean Crop. Insect Science and Application, 11, 97-101. http://dx.doi.org/10.1017/s1742758400019901

[27] Dangl, J.L. and Jones, J.D. (2001) Plant Pathogens and Integrated Defence Responses to Infection. Nature, 411, 826833. http://dx.doi.org/10.1038/35081161

[28] Cammell, M. and Knight, J. (1992) Effects of Climatic Change on the Population Dynamics of Crop Pests. Advances in Ecological Research, 22, 117-162. http://dx.doi.org/10.1016/S0065-2504(08)60135-X

[29] Stoddard, F., Nicholas, A., Rubiales, D., Thomas, J. and Villegas-Fernández, A. (2010) Integrated Pest Management in Faba Bean. Field Crops Research, 115, 308-318. http://dx.doi.org/10.1016/j.fcr.2009.07.002

[30] Flint, M.L., Dreistadt, S.H. and Clark, J.K. (1998) Natural Enemies Handbook: The Illustrated Guide to Biological Pest Control. University of California Press, Oakland.

[31] Chapman, R., Bernays, E. and Simpson, S. (1981) Attraction and Repulsion of the Aphid, Cavariella aegopodii, by Plant Odors. Journal of Chemical Ecology, 7, 881-888. http://dx.doi.org/10.1007/BF00992385

[32] Dadd, R. (1963) Feeding Behaviour and Nutrition in Grasshoppers and Locusts. Advances in Insect Physiology, 1, 47109. http://dx.doi.org/10.1016/S0065-2806(08)60174-5 
[33] Mwanauta, R.W., Mtei, K.M. and Ndakidemi, P.A. (2015) Potential of Controlling Common Bean Insect Pests (Bean Stem Maggot (Ophiomyia phaseoli), Ootheca (Ootheca bennigseni) and Aphids (Aphis fabae) Using Agronomic, Biological and Botanical Practices in Field. Agricultural Sciences, 6, 489-497. http://dx.doi.org/10.4236/as.2015.65048

[34] Copping, L.G. and Menn, J.J. (2000) Biopesticides: A Review of Their Action, Applications and Efficacy. Pest Management Science, 56, 651-676. http://dx.doi.org/10.1002/1526-4998(200008)56:8<651::AID-PS201>3.0.CO;2-U

[35] Alavanja, M.C. (2009) Introduction: Pesticides Use and Exposure, Extensive Worldwide. Reviews on Environmental Health, 24, 303-310. http://dx.doi.org/10.1515/REVEH.2009.24.4.303

[36] Williamson, S., Ball, A. and Pretty, J. (2008) Trends in Pesticide Use and Drivers for Safer Pest Management in Four African Countries. Crop Protection, 27, 1327-1334. http://dx.doi.org/10.1016/j.cropro.2008.04.006

[37] Nyirenda, S.P., Sileshi, G.W., Belmain, S.R., Kamanula, J.F., Mvumi, B.M., Sola, P., Nyirenda, G.K. and Stevenson, P.C. (2011) Farmers' Ethno-Ecological Knowledge of Vegetable Pests and Pesticidal Plant Use in Malawi and Zambia. African Journal of Agricultural Research, 6, 1525-1537.

[38] Kapeya, E., Chirwa, R. and Mviha, P. (2005) Development of an Integrated Pest and Resource Management Package for the Control of Bean Stem Maggot (Ophiomyia spp.) in Malawi. Paper Presented at the PABRA Millennium Workshop, 182.

[39] Scaife, A. and Turner, M. (1983) Diagnosis of Mineral Disorders in Plants: Volume 2, Vegetables. Her Majesty’s Stationery Office, London.

[40] Elserougy, S., Beshir, S., Saad-Hussein, A. and Abou Arab, A. (2013) Organochlorine Pesticide Residues in Biological Compartments of Healthy Mothers. Toxicology and Industrial Health, 29, 441-448.

[41] Prakash, A., Rao, J. and Nandagopal, V. (2008) Future of Botanical Pesticides in Rice, Wheat, Pulses and Vegetables Pest Management. Journal of Biopesticides, 1, 154-169.

[42] Isman, M.B. (2006) Botanical Insecticides, Deterrents, and Repellents in Modern Agriculture and an Increasingly Regulated World. Annual Review of Entomology, 51, 45-66. http://dx.doi.org/10.1146/annurev.ento.51.110104.151146

[43] Offor, C., Okaka, A. and Aja, P. (2014) Comparative Analyses on the Effects of Ethanol Leaf-Extracts of Vernonia amygdalina and Azadirachta indica on Lipid Profile in Albino Rats. World Applied Sciences Journal, 32, 61-65.

[44] Arannilewa, S., Ekrakene, T. and Akinneye, J. (2006) Laboratory Evaluation of Four Medicinal Plants as Protectants against the Maize Weevil, Sitophilus zeamais (Mots). African Journal of Biotechnology, 5, 2032-2036.

[45] Roy, B., Amin, R., Uddin, M., Islam, A., Islam, M. and Halder, B. (2005) Leaf Extracts of Shiyalmutra (Blumea lacera DC.) as Botanical Insecticides against Lesser Grain Borer and Rice Weevil. Journal of Biological Science, 5, 201-204. http://dx.doi.org/10.3923/jbs.2005.201.204

[46] Koona, P. and Dorn, S. (2005) Extracts from Tephrosia vogelii for the Protection of Stored Legume Seeds against Damage by Three Bruchid Species. Annals of applied biology, 147, 43-48. http://dx.doi.org/10.1111/j.1744-7348.2005.00006.x

[47] Sharma, O.P., Sharma, S., Pattabhi, V., Mahato, S.B. and Sharma, P.D. (2007) A Review of the Hepatotoxic Plant Lantana camara. Critical Reviews in Toxicology, 37, 313-352. http://dx.doi.org/10.1080/10408440601177863

[48] Kareru, P., Maina, E.W. and Rotich, Z.K. (2013) Use of Botanicals and Safer Insecticides Designed in Controlling Insects: The African Case. INTECH Open Access Publisher, Winchester.

[49] Bhatt, P., Thodsare, N. and Srivastava, R. (2014) Toxicity of Some Bioactive Medicinal Plant Extracts to Asian Army Worm, Spodoptera litura. Journal of Applied and Natural Science, 6, 139-143.

[50] Hinson, D. (2000) Rotenone Characterization and Toxicity in Aquatic Systems. Principles of Environmental Toxicity. University of Idaho, Moscow.

[51] Khater, H.F. (2012) Prospects of Botanical Biopesticides in Insect Pest Management. Pharmacologia, 3, 641-656. http://dx.doi.org/10.5567/pharmacologia.2012.641.656

[52] Aerts, R.J. and Mordue, A.J. (1997) Feeding Deterrence and Toxicity of Neem Triterpenoids. Journal of Chemical Ecology, 23, 2117-2132. http://dx.doi.org/10.1023/B:JOEC.0000006433.14030.04

[53] Khalil, M.S. (2013) Abamectin and Azadirachtin as Eco-Friendly Promising Biorational Tools in Integrated Nematodes Management Programs. Journal of Plant Pathology and Microbiology, 1, 1-7. http://dx.doi.org/10.4172/2157-7471.1000174

[54] Ambrósio, S.R., Oki, Y., Heleno, V.C.G., Chaves, J.S., Nascimento, P.G.B.D., Lichston, J.E., Constantino, M.G., Varanda, E.M. and Da Costa, F.B. (2008) Constituents of Glandular Trichomes of Tithonia diversifolia: Relationships to Herbivory and Antifeedant Activity. Phytochemistry, 69, 2052-2060. http://dx.doi.org/10.1016/j.phytochem.2008.03.019

[55] Chagas-Paula, D.A., de Oliveira, R.B., da Silva, V.C., Gobbo-Neto, L., Gasparoto, T.H., Campanelli, A.P., Faccioli, L.H. and Da Costa, F.B. (2011) Chlorogenic Acids from Tithonia diversifolia Demonstrate Better Anti-Inflammatory 
Effect Than Indomethacin and Its Sesquiterpene Lactones. Journal of Ethnopharmacology, 136, 355-362. http://dx.doi.org/10.1016/j.jep.2011.04.067

[56] Passoni, F.D., Oliveira, R.B., Chagas-Paula, D.A., Gobbo-Neto, L. and Da Costa, F.B. (2013) Repeated-Dose Toxicological Studies of Tithonia diversifolia (Hemsl.) A. Gray and Identification of the Toxic Compounds. Journal of Ethnopharmacology, 147, 389-394. http://dx.doi.org/10.1016/j.jep.2013.03.024

[57] Obafemi, C., Sulaimon, T., Akinpelu, D. and Olugbade, T. (2009) Antimicrobial Activity of Extracts and a Germacranolidetype Sesquiterpene Lactone from Tithonia diversifolia Leaf Extract. African Journal of Biotechnology, 5, 12541258.

[58] Ross, I.A. (1999) Medicinal Plants of the World: Chemical Constituents, Traditional and Modern Medicinal Uses. Humana Press, New York.

[59] Barceloux, D.G. (2012) Medical Toxicology of Natural Substances: Foods, Fungi, Medicinal Herbs, Plants, and Venomous Animals. John Wiley \& Sons, Hoboken.

[60] Yuan, Z. and Hu, X.P. (2012) Repellent, Antifeedant, and Toxic Activities of Lantana camara Leaf Extract against Reticulitermes flavipes (Isoptera: Rhinotermitidae). Journal of Economic Entomology, 105, 2115-2121. http://dx.doi.org/10.1603/EC12026

[61] Begum, S., Wahab, A., Siddiqui, B.S. and Qamar, F. (2000) Nematicidal Constituents of the Aerial Parts of Lantana camara. Journal of Natural Products, 63, 765-767. http://dx.doi.org/10.1021/np9903548

[62] Rajashekar, Y., Raghavendra, A. and Bakthavatsalam, N. (2014) Acetylcholinesterase Inhibition by Biofumigant (Coumaran) from Leaves of Lantana camara in Stored Grain and Household Insect Pests. BioMed Research International, 2014, 1-6. http://dx.doi.org/10.1155/2014/187019

[63] Abdullahi, M., Uba, A., Yaro, A., Maxwell, O., Yusuf, A., Kabir, S., Alhasan, A., Umar, A., Bello, S. and Nasir, I. (2015) Phytochemical Screening, Acute Toxicity Study and Evaluation of Antidiabetic Properties of the Methanolic Leaf Extract of Vernonia glaberrima (Asteraceae). Journal Pharmacology, Chemical and Biological Sciences, 3, 169177.

[64] Erasto, P., Adebola, P., Grierson, D. and Afolayan, A. (2005) An Ethnobotanical Study of Plants Used for the Treatment of Diabetes in the Eastern Cape Province, South Africa. African Journal of Biotechnology, 4, 1454-1460.

[65] Erasto, P., Grierson, D. and Afolayan, A. (2006) Bioactive Sesquiterpene Lactones from the Leaves of Vernonia amygdalina. Journal of Ethnopharmacology, 106, 117-120. http://dx.doi.org/10.1016/j.jep.2005.12.016

[66] Favi, F., Cantrell, C.L., Mebrahtu, T. and Kraemer, M.E. (2008) Leaf Peltate Glandular Trichomes of Vernonia galamensis ssp. galamensis var. ethiopica Gilbert: Development, Ultrastructure, and Chemical Composition. International Journal of Plant Sciences, 169, 605-614. http://dx.doi.org/10.1086/533598

[67] Asawalam, E. and Osondu, H. (2013) Control of Field Insect Pests of Cowpea (Vigna unguiculata L. Walp) in Umudike Nigeria Using Medicinal Plant Extracts. Journal of Sustainable Agriculture and the Environment, 14, 31-37.

[68] Ijeh, I. and Obidoa, O. (2004) Effect of Dietary Incorporation of Vernonia amygdalina. del on AFB1 Induced Hepatotoxocity in Weanling Albino Rats. Jamaican Journal of Science and Technology, 15, 32-36.

[69] Belmain, S.R., Amoah, B.A., Nyirenda, S.P., Kamanula, J.F. and Stevenson, P.C. (2012) Highly Variable Insect Control Efficacy of Tephrosia vogelii Chemotypes. Journal of Agricultural and Food Chemistry, 60, 10055-10063. http://dx.doi.org/10.1021/jf3032217

[70] Mordue, A. and Blackwell, A. (1993) Azadirachtin: An Update. Journal of Insect Physiology, 39, 903-924. http://dx.doi.org/10.1016/0022-1910(93)90001-8

[71] Zoubiri, S. and Baaliouamer, A. (2012) Chemical Composition and Insecticidal Properties of Lantana camara L. Leaf Essential Oils from Algeria. Journal of Essential Oil Research, 24, 377-383. http://dx.doi.org/10.1080/10412905.2012.692910

[72] Sharma, O., Dawra, R. and Makkar, H. (1987) Isolation and Partial Purification of Lantana (Lantana camara L.) Toxins. Toxicology Letters, 37, 165-172. http://dx.doi.org/10.1016/0378-4274(87)90153-6

[73] Sharma, O.P., Vaid, J., Pattabhi, V. and Bhutani, K.K. (1992) Biological Action of Lantadene C, a New Hepatotoxicant from Lantana camara var. aculeata. Journal of Biochemical Toxicology, 7, 73-79. http://dx.doi.org/10.1002/jbt.2570070204 